MATEC Web of Conferences 9, 02009 (2013)

DOI: $10.1051 /$ matecconf/20130902009

(C) Owned by the authors, published by EDP Sciences, 2013

\title{
Fire resistance tests of large glazed aluminium curtain wall test specimens - results comparison
}

\author{
Bartłomiej Sędłak ${ }^{1,2, a}$, Jacek Kinowski ${ }^{1, b}$ and Andrzej Borowy ${ }^{1, c}$ \\ ${ }^{1}$ Fire Research Department of Building Research Institute, Ksawerów 21, 02-656 Warsaw, \\ Poland \\ ${ }^{2}$ Military University of Technology, Kaliskiego 2, 00-908 Warsaw, Poland
}

\section{INTRODUCTION}

In this paper comparison of fire resistance test results of large - minimum dimension of $5250 \times 5725 \mathrm{~mm}$ (width $\mathrm{x}$ height) - glazed aluminium curtain wall test specimens is presented. Comparison has been made for different sides of fire exposure, different material of profile insulation inserts and different thickness of glass panes.

\section{TEST SPECIMENS}

Four test specimens, glazed aluminium curtain walls in full configuration, were tested. Curtain walls had the same transom - mullion structure, with:

- transoms and mullions made of the same aluminium profiles, with two types of insulation inserts (in each test one type of the insulation inserts),

- glass panes of the same glass product group and dimensions of:

- $1680 \times 3198 \mathrm{~mm}$ (width $\times$ height) for biggest glass pane orientated vertically,

- $1980 \times 1628 \mathrm{~mm}$ (width $\times$ height) for biggest glass pane orientated horizontally.

- non-transparent panels of the same construction and dimensions,

- similar design (profiles, and consequently glass panes and panels of the same construction on the exposed area).

Two test specimens were tested for external fire exposure, and two for standard fire exposure.

Dimensions of exposed surfaces were $5000 \times 4500 \mathrm{~mm}$ (width $\times$ height) for external fire exposure and $5000 \times 4800 \mathrm{~mm}$ (width $\times$ height) for internal fire exposure. As a result the heated area was over 2 times greater than the minimum heated area required in EN 1364-3:2006 [3]. The distance between the mullion fixing anchors was $5000 \mathrm{~mm}$ in both cases.

All tested specimens were of the same transom - mullion structure with aluminium profiles sections of $50 \times 115 \mathrm{~mm}$ (transoms) and $50 \times 130 \mathrm{~mm}$ (mullions), fig. 1. Two types of insulations inserts were used in profiles, each type for pair of tests (external and internal fire exposure). Two types of glass panes were used in test specimens, each type for pair of tests (external and internal fire exposure). Glass panes were of symmetrical structure.

\footnotetext{
a e-mail: b.sedlak@itb.pl

be-mail: j.kinowski@itb.pl

ce-mail: a. borowy@itb.pl

This is an Open Access article distributed under the terms of the Creative Commons Attribution License 2.0, which permits unrestricted use, distribution, and reproduction in any medium, provided the original work is properly cited.
} 
MATEC Web of Conferences
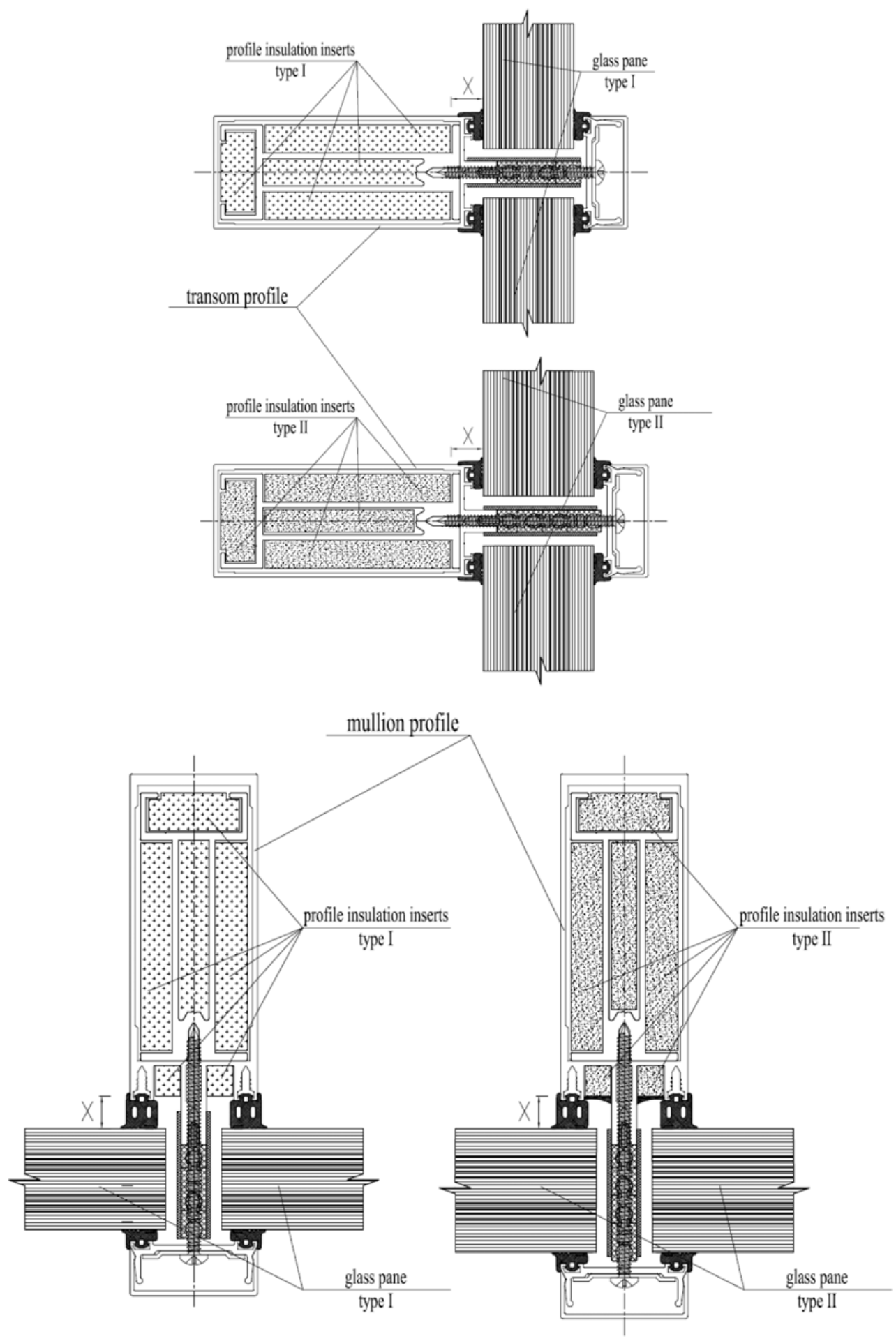

Figure 1. Mullions and transoms cross - section. 
$1^{\text {st }}$ International Seminar for Fire Safety of Facades, Paris (France), 2013

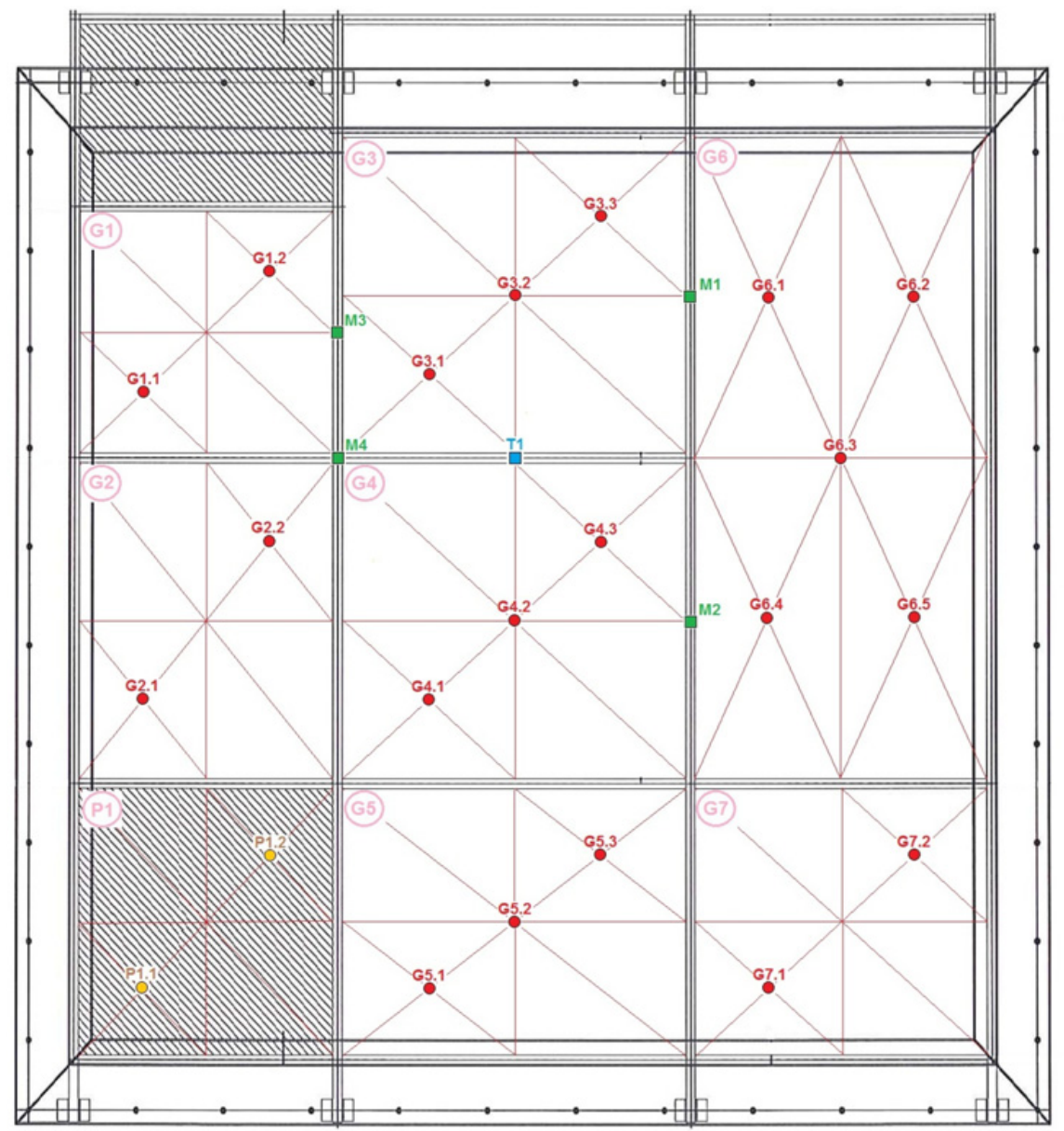

(x) glass panes/panels numeration

- Gx.y thermocouples for average (maximum) temperature rise (glass panes)

Px.y thermocouples for average (maximum) temperature rise (panel)

a $M x$ thermocouples for maximum temperature rise (mullions)

- TX thermocouple for maximum temperature rise (transom)

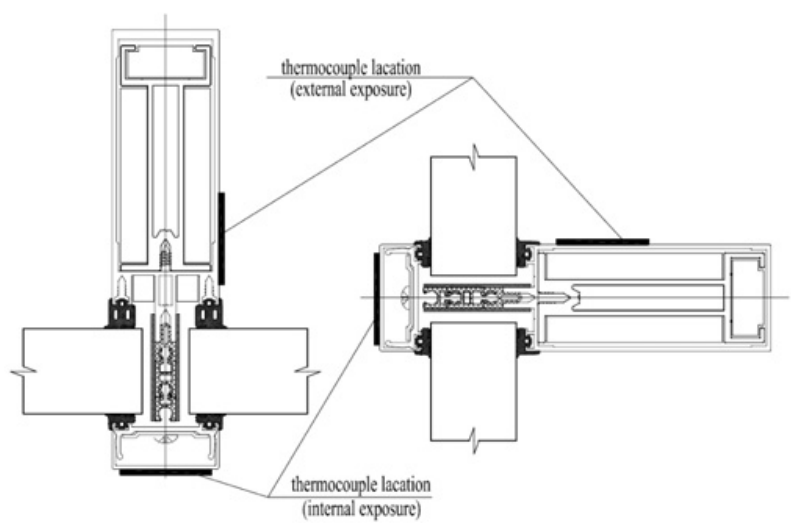

Figure 2. Thermocouples arrangement on the unexposed surface of tested specimen and location of the thermocouples on the profiles. 
MATEC Web of Conferences

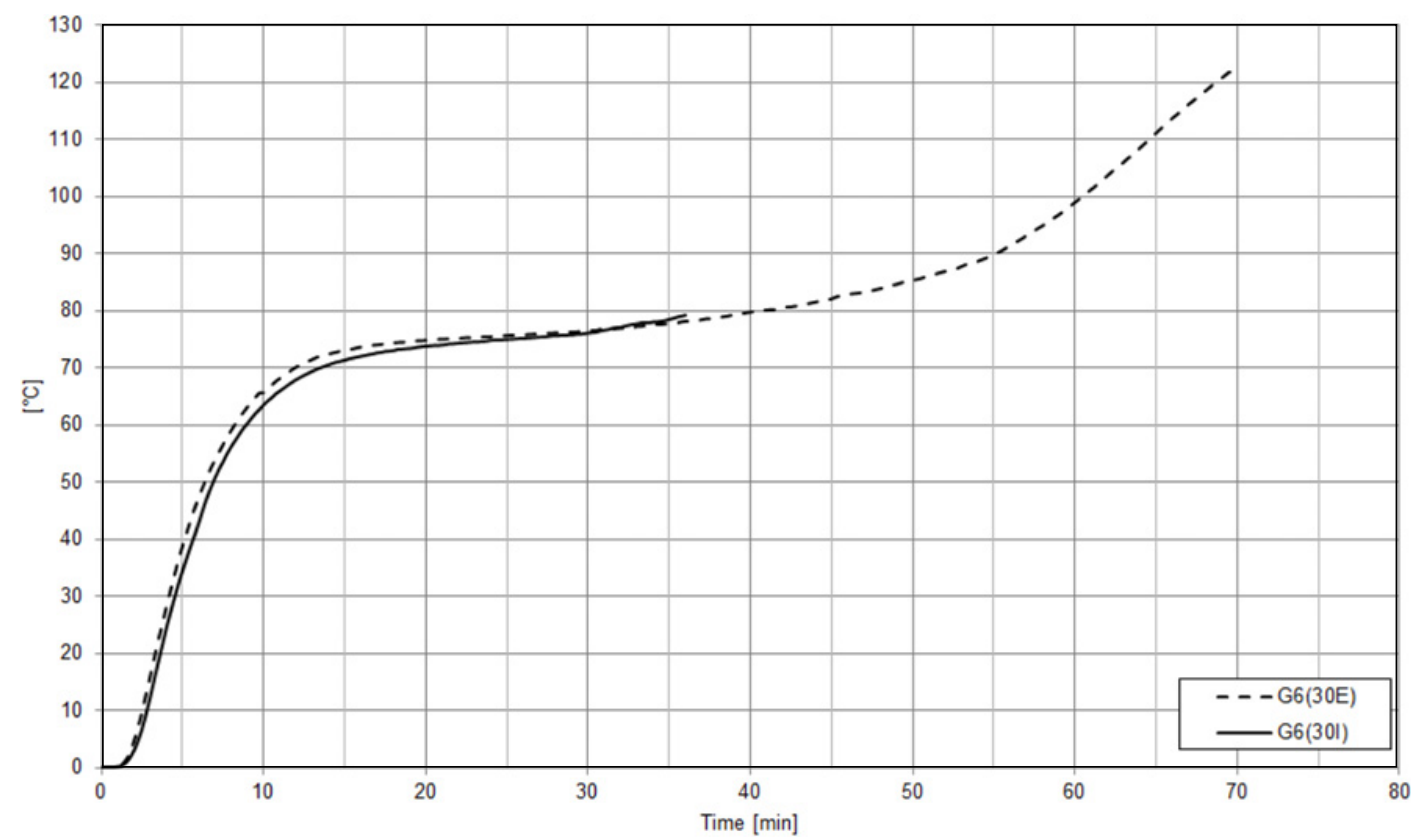

Figure 3. Comparison of average temperature rises on unexposed surface of glass pane with the largest area depending on the side of fire exposure; glass pane type 1; G6(30E) - external fire exposure, G6(30I) - internal fire exposure.

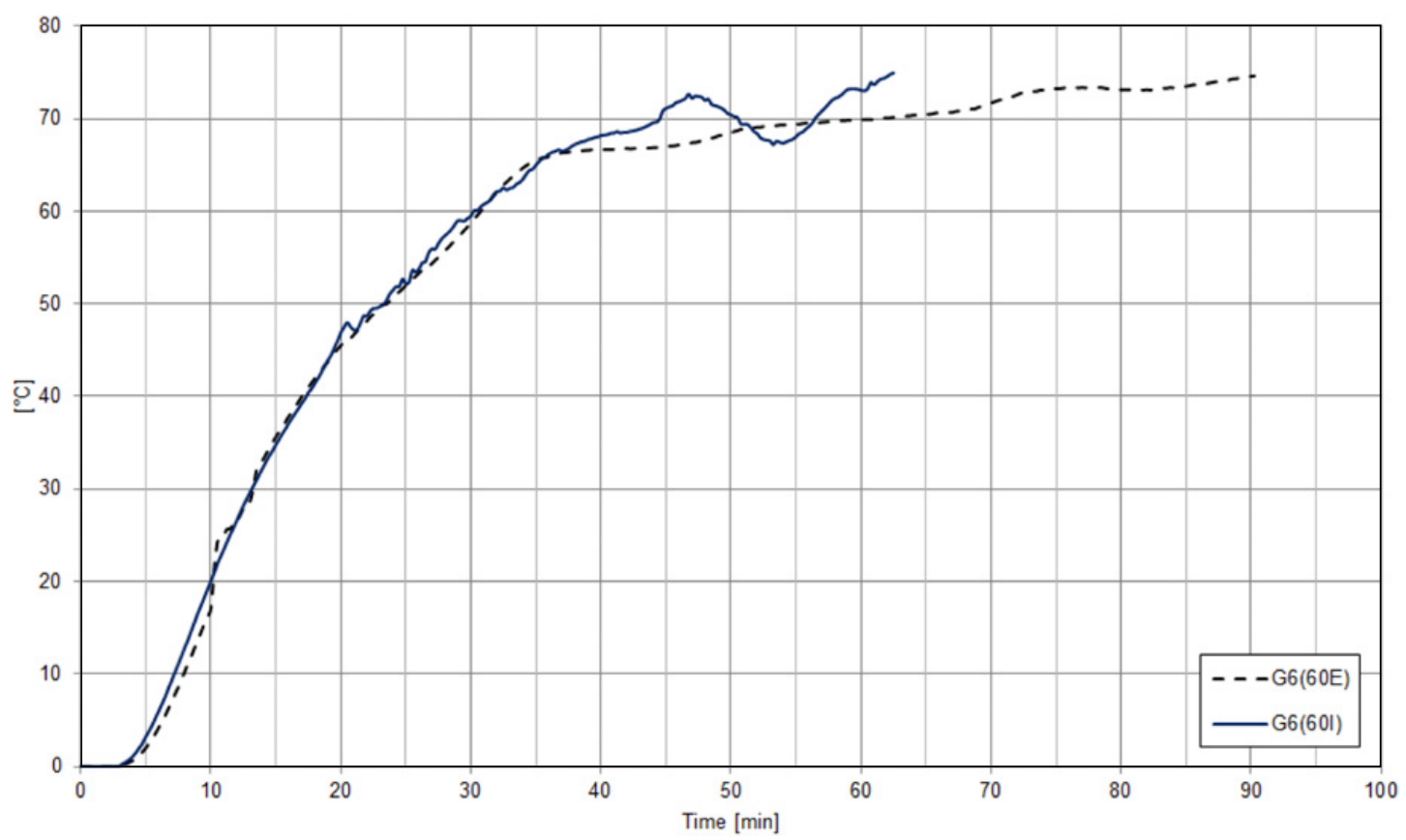

Figure 4. Comparison of average temperature rises on unexposed surface of glass pane with the largest area depending on the side of fire exposure; glass pane type 2; G6(60E) - external fire exposure, G6(60I) - internal fire exposure. 
$1^{\text {st }}$ International Seminar for Fire Safety of Facades, Paris (France), 2013

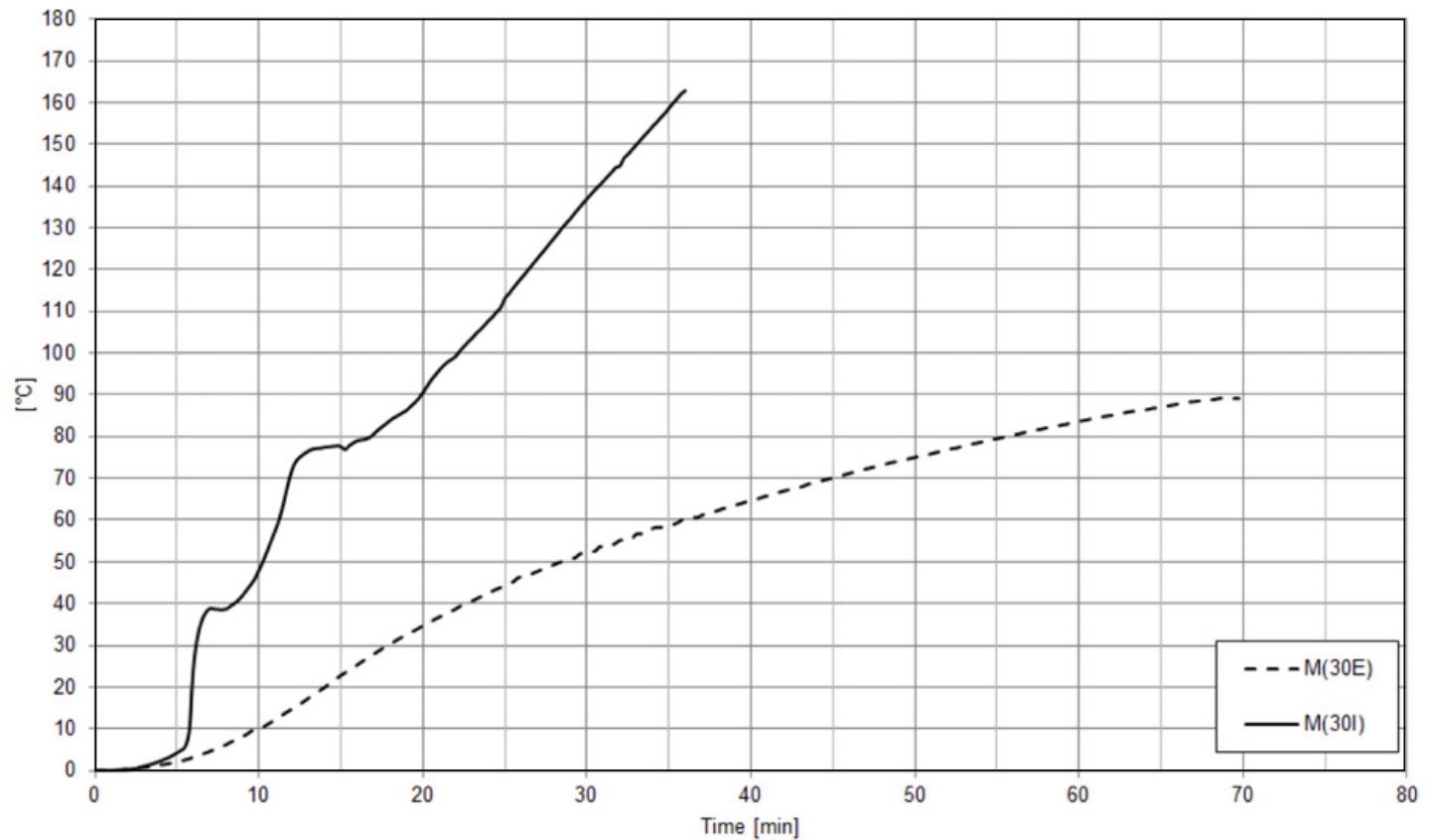

Figure 5. Comparison of average temperature rises on unexposed surface of mullions depending on the side of fire exposure; insulation insert type 1; M(30E) - external fire exposure, $\mathrm{M}(30 \mathrm{I})$ - internal fire exposure.

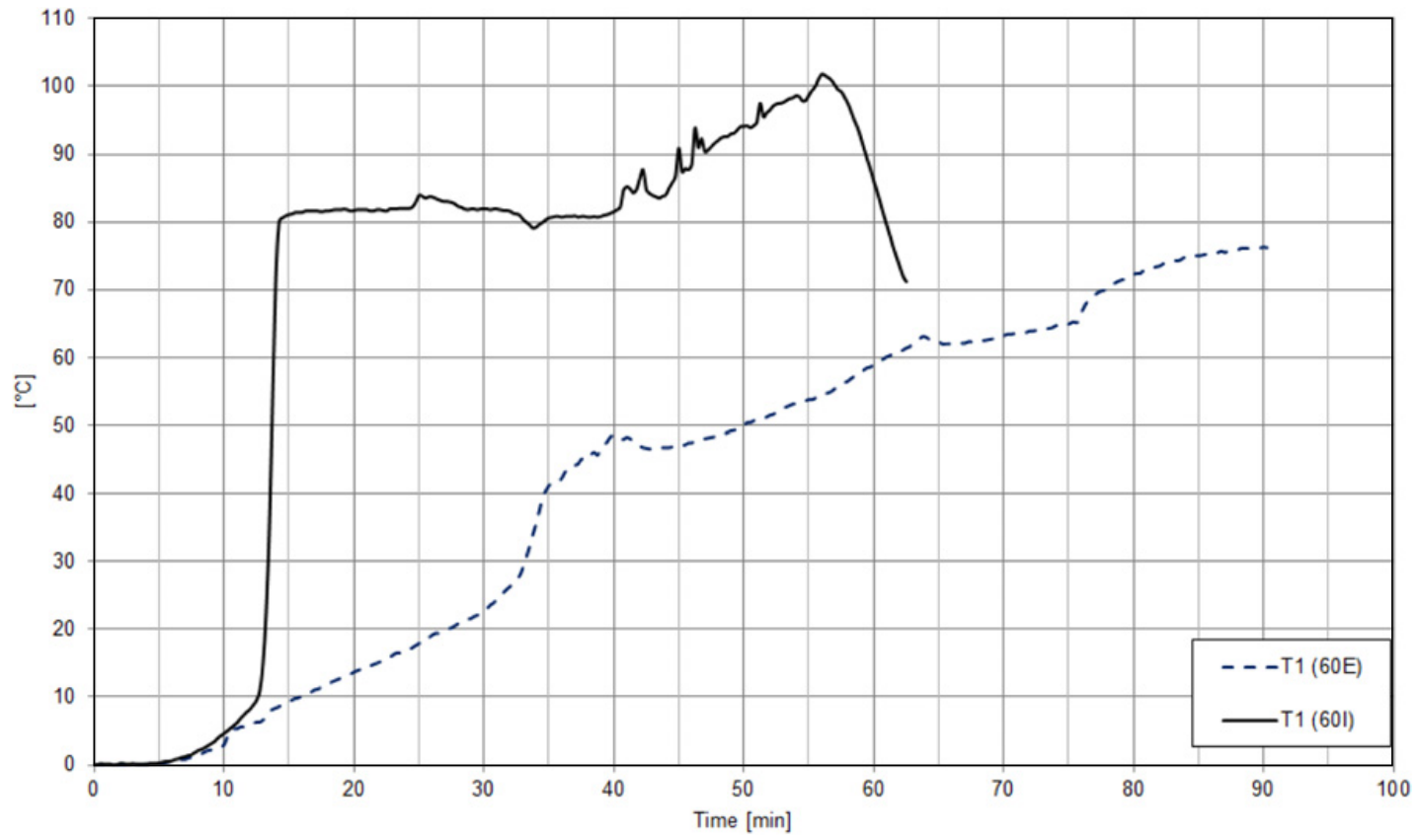

Figure 6. Comparison of average temperature rises on unexposed surface of transoms depending on the side of fire exposure; insulation insert type 2; T(60E) - external fire exposure, $\mathrm{T}(60 \mathrm{I})$ - internal fire exposure. 
MATEC Web of Conferences

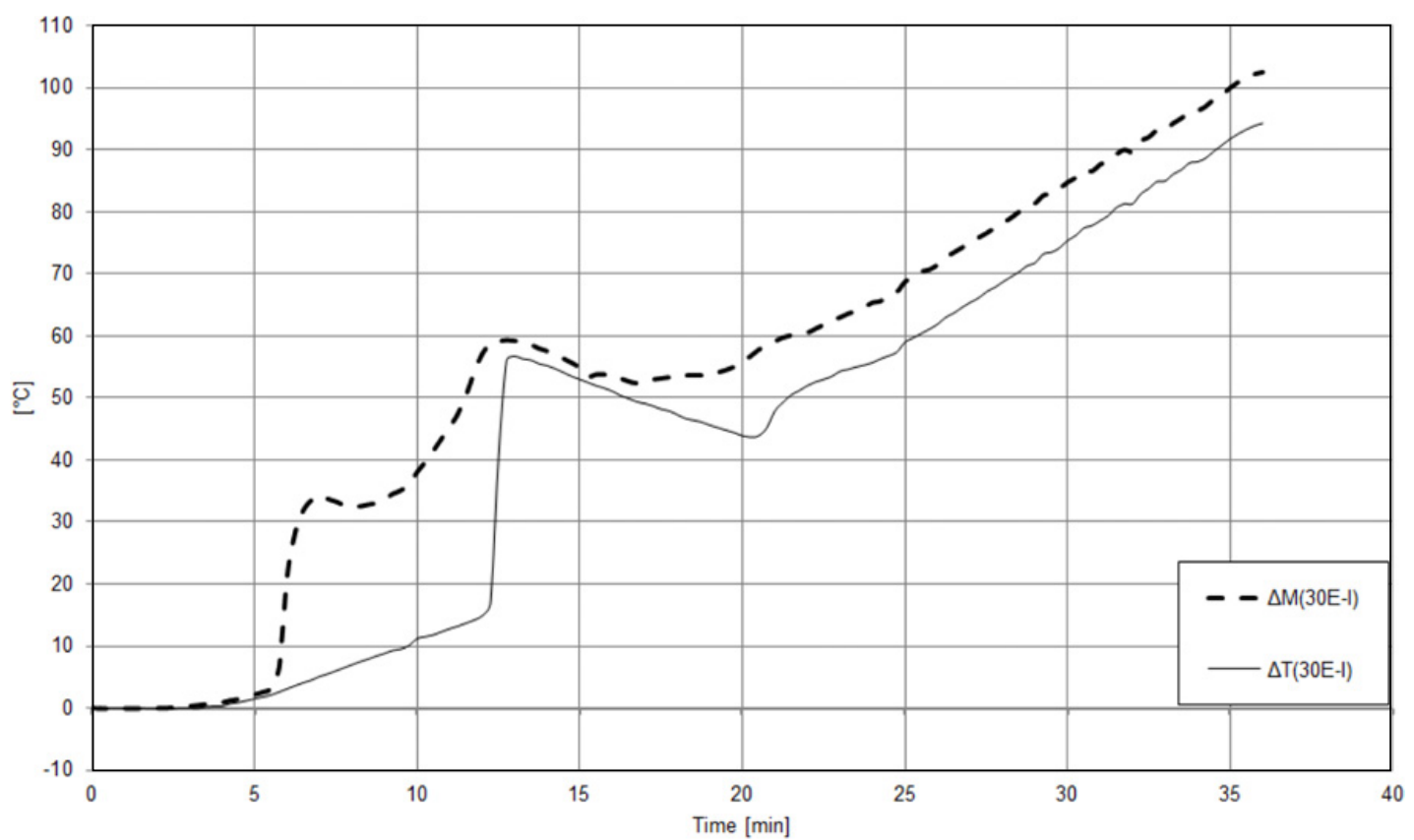

Figure 7. Differences between the average temperature rises on the unexposed surface of specimen tested for external fire exposure and specimen tested for internal fire exposure; insulation inserts type $1, \Delta \mathrm{M}(30 \mathrm{E}-\mathrm{I})-$ mullions, $\Delta \mathrm{T}(30 \mathrm{E}-\mathrm{I})-$ transoms.

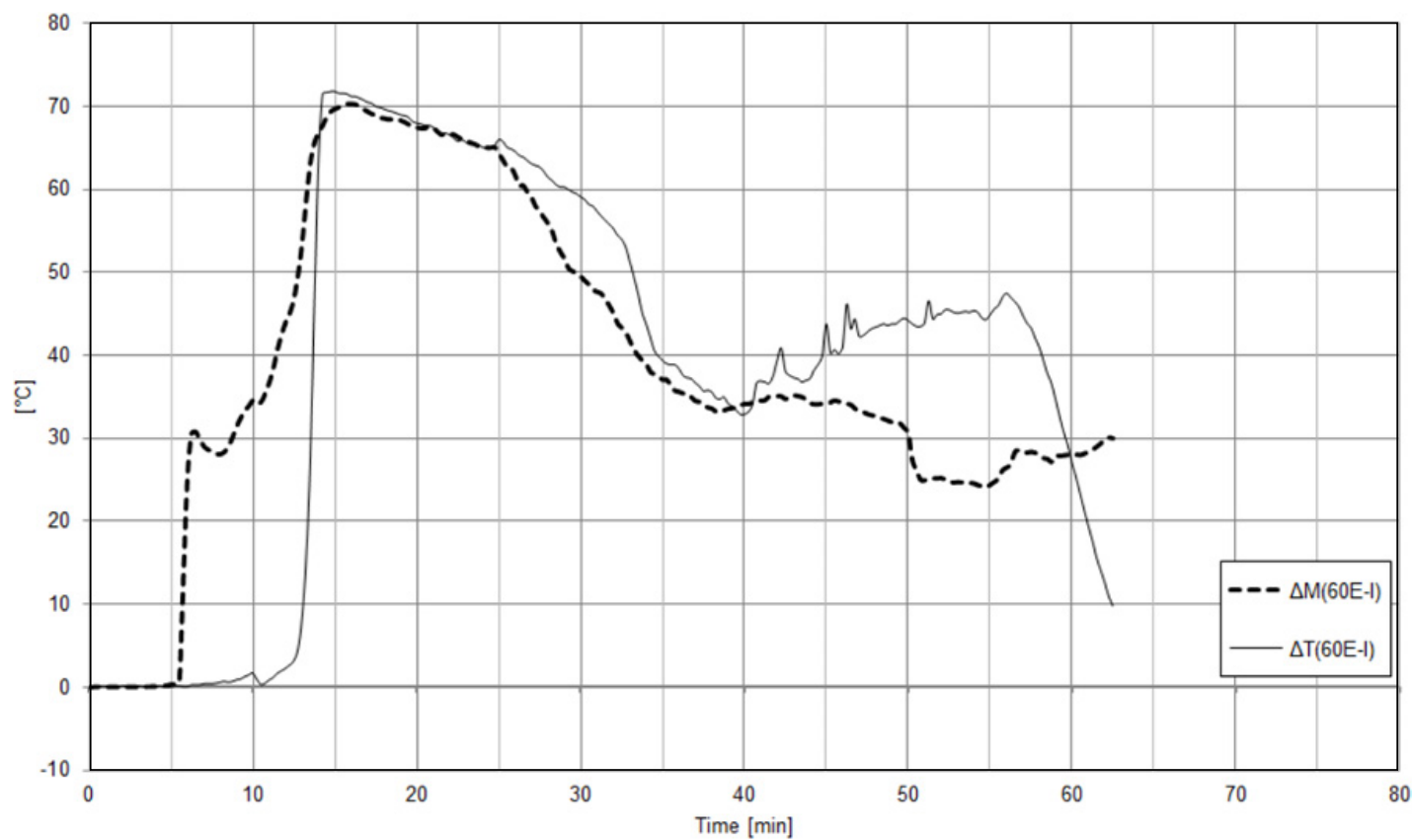

Figure 8. Differences between the average temperature rises on the unexposed surface of specimen tested for external fire exposure and specimen tested for internal fire exposure; insulation inserts type $2, \Delta \mathrm{M}(60 \mathrm{E}-\mathrm{I})-$ mullions, $\Delta \mathrm{T}(60 \mathrm{E}-\mathrm{I})-$ transoms. 
$1^{\text {st }}$ International Seminar for Fire Safety of Facades, Paris (France), 2013

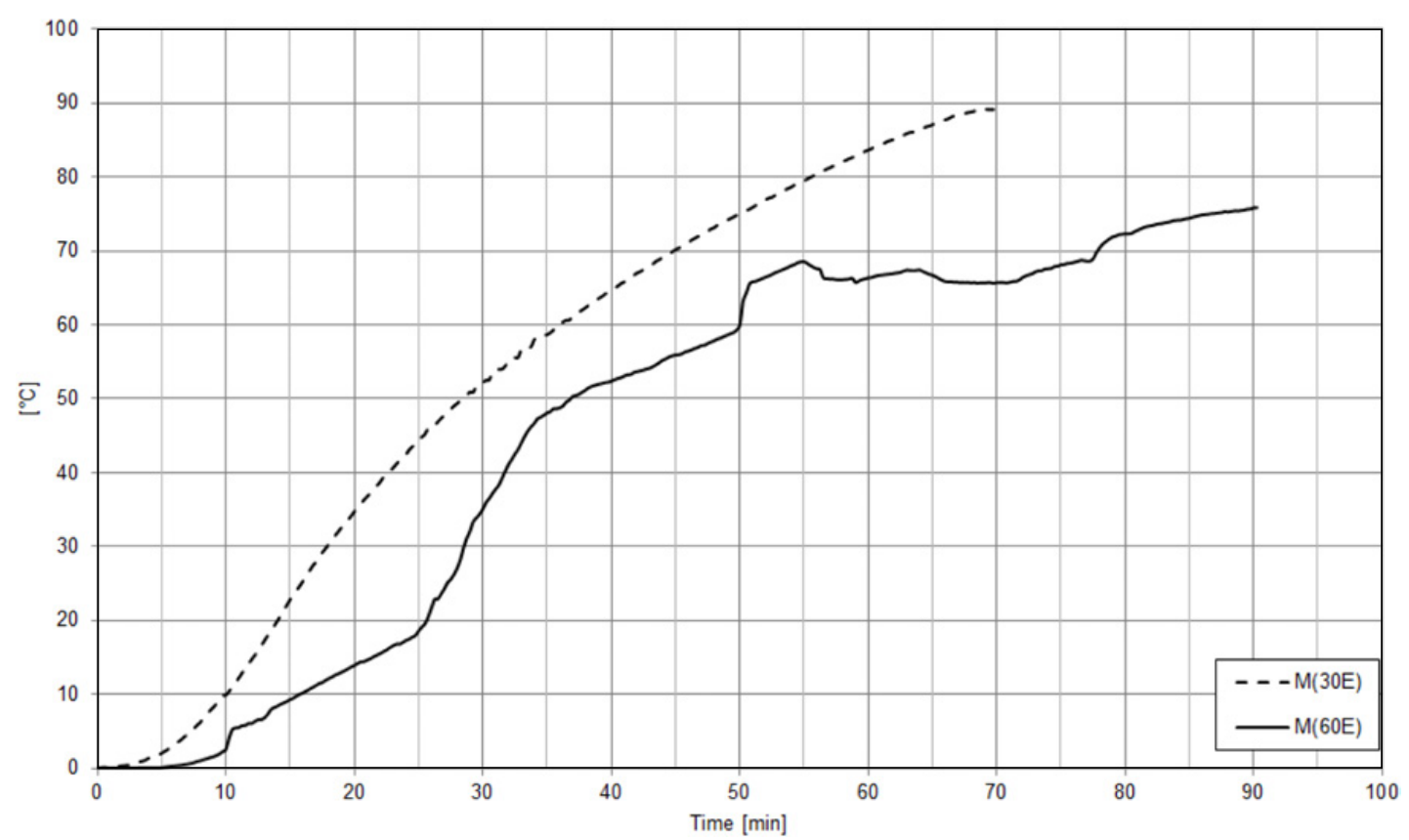

Figure 9. Comparison of average temperature rises on unexposed surface of mullions depending on the type of insulations inserts, external fire exposure; $\mathrm{M}(30 \mathrm{E})$ - insulation inserts type 1, M(60E) - insulation inserts type 2.

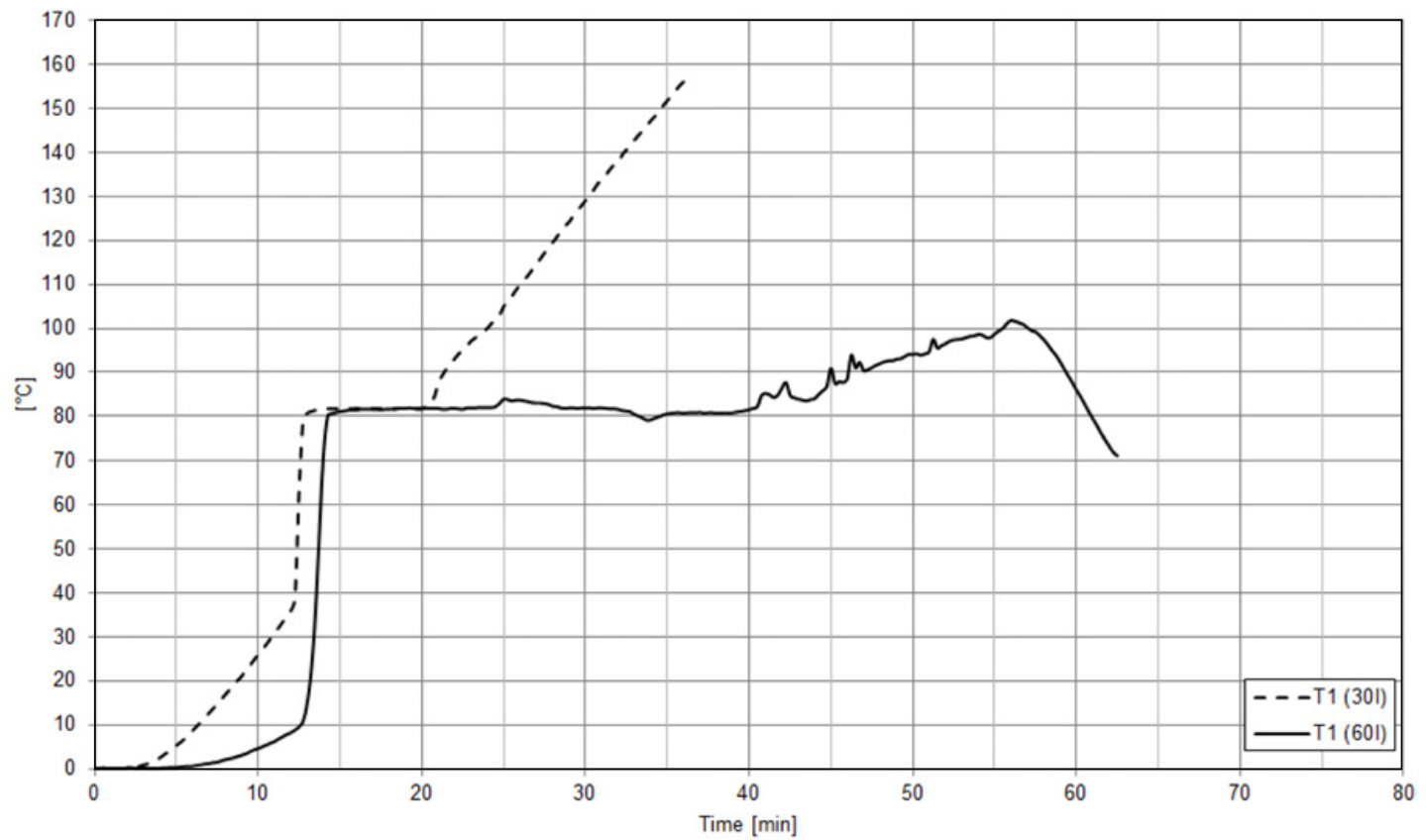

Figure 10. Comparison of average temperature rises on unexposed surface of mullions depending on the type of insulations inserts, internal fire exposure; T(30I) - insulation inserts type 1, T(60I) - insulation inserts type 2. 
MATEC Web of Conferences

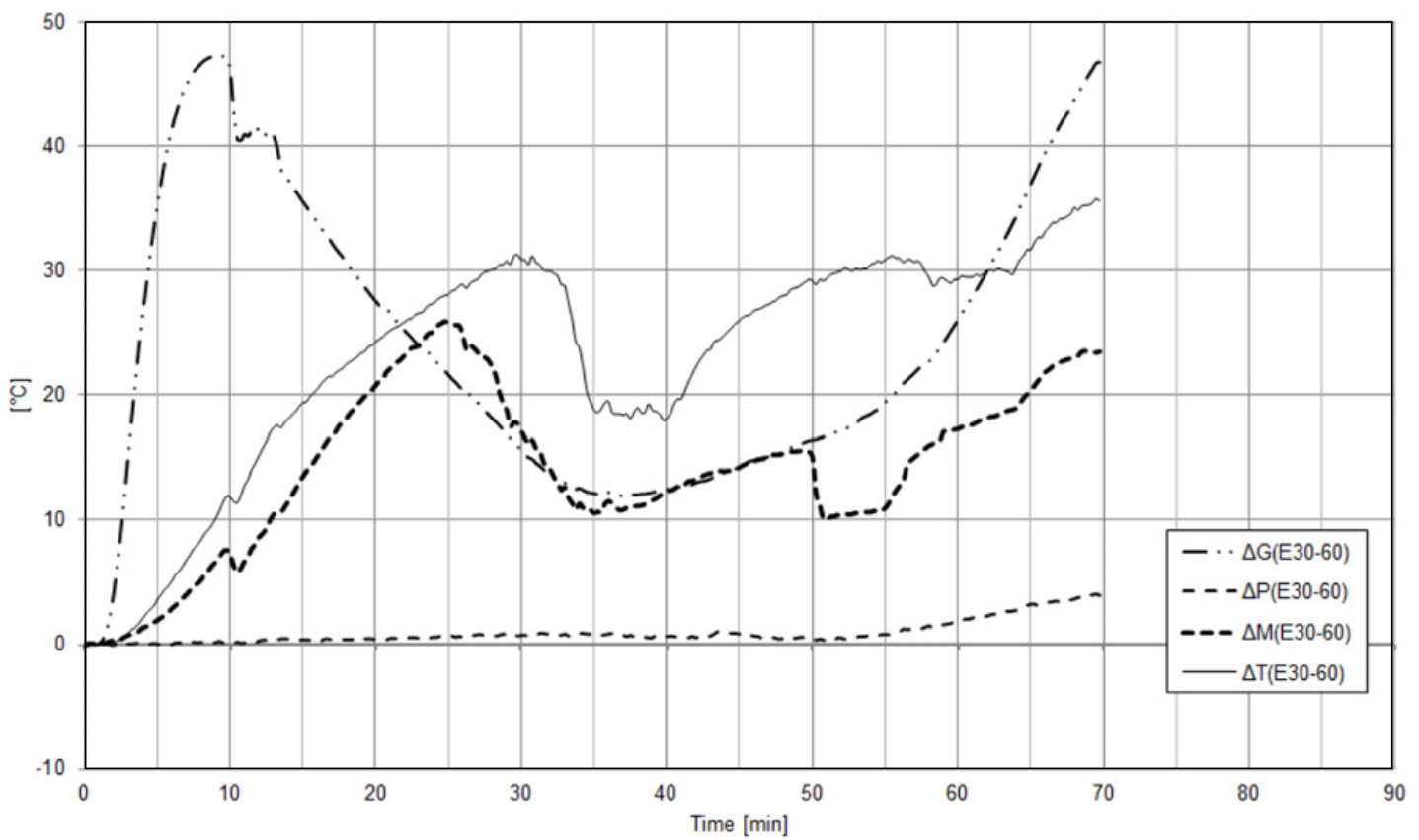

Figure 11. Differences between the average temperature rises on the unexposed surface of test specimens with insulation inserts and glass panes type No. 1 and type No. 2, external fire exposure; $\Delta \mathrm{G}(\mathrm{E} 30-60)$ - glass panes, $\Delta \mathrm{P}(\mathrm{E} 30-60)$ - panels, $\Delta \mathrm{M}(\mathrm{E} 30-60)-$ mullions, $\Delta \mathrm{T}(\mathrm{E} 30-60)$ - transoms.

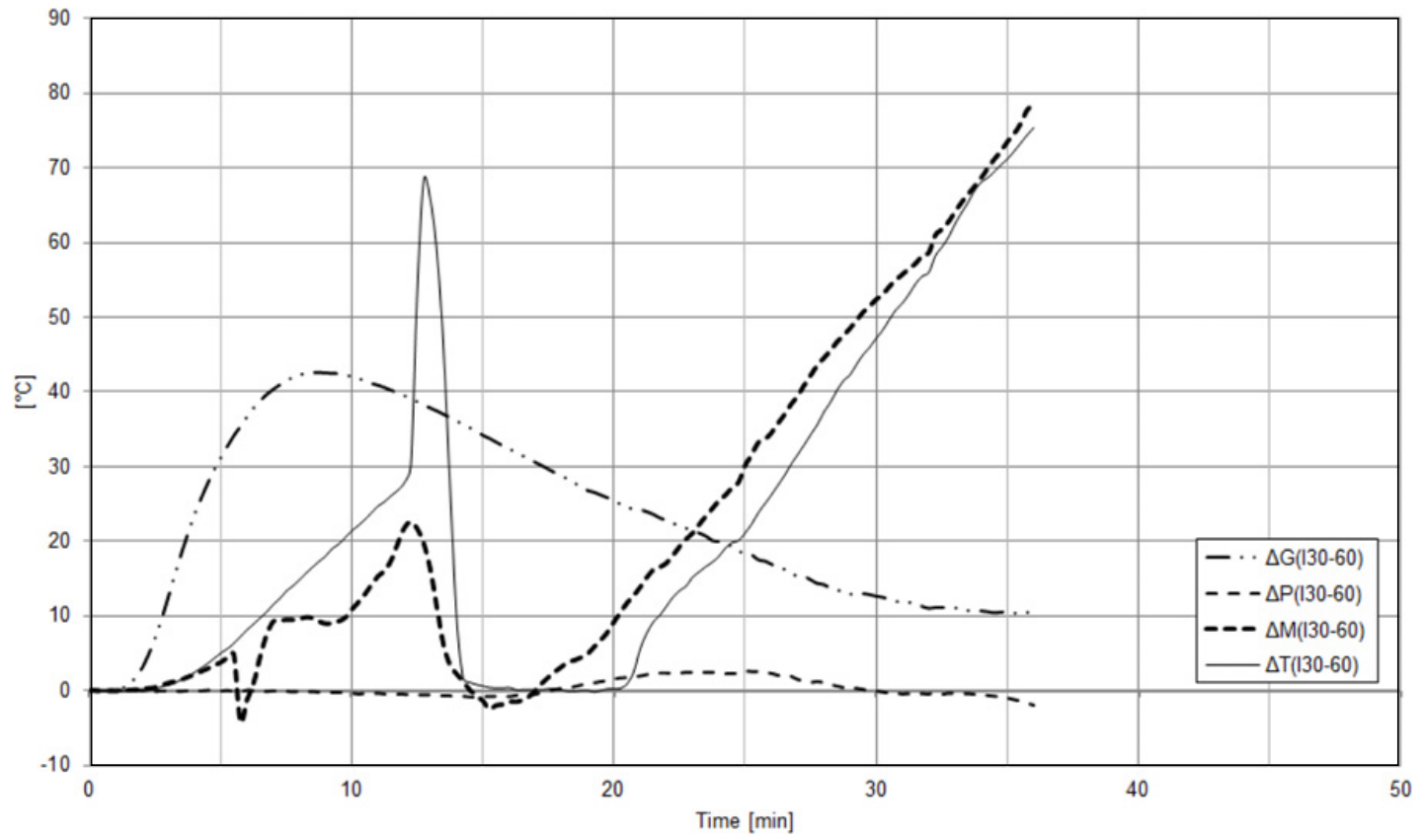

Figure 12. Differences between the average temperature rises on the unexposed surface of test specimens with insulation inserts and glass panes type No. 1 and type No. 2, internal fire exposure; $\Delta \mathrm{G}(\mathrm{I} 30-60)$ - glass panes, $\Delta \mathrm{P}(\mathrm{I} 30-60)$ - panels, $\Delta \mathrm{M}(\mathrm{I} 30-60)-$ mullions, $\Delta \mathrm{T}(\mathrm{I} 30-60)$ - transoms. 


\section{INSTRUMENTATION}

The temperature rise on unexposed surface of the test specimens was measured with surface thermocouples type K specified in EN 1363-1:2012 [1]. Thermocouples arrangement (the same for all of the tests) is given in Fig. 2. Location of the thermocouple on the transom and mullion profiles is presented in Fig. 2.

\section{FIRE RESISTANCE TESTS}

Four fire resistance tests of glazed aluminium curtain wall in full configuration (complete assembly) were conducted in Fire Testing Laboratory of Building Research Institute in Pionki:

- two tests of glazed aluminium curtain walls dimensions of $5250 \times 5725 \mathrm{~mm}$ (width $\mathrm{x}$ height) heated from the glazing beads side under external fire exposure in accordance with EN 1363-2:1999 [2],

- two tests of glazed aluminium curtain walls dimensions of $5850 \times 5725 \mathrm{~mm}$ (width $\mathrm{x}$ height) heated from the side opposite to glazing beads (profile side) under standard fire exposure in accordance with EN 1363-1:2012 [1].

\section{TEST RESULTS}

The most interesting results obtained during the tests are presented in Figs. 3-12.

Comparison of average temperature rises on unexposed surface of tested specimen depending on the side of fire exposure is presented in Figs. 3-6. Differences between the average temperature rises on the unexposed surface of tested specimen heated from outside and from inside are presented in Figs. 7-8. Comparison of average temperature rises on unexposed surface of the profiles depending on the type of insulations inserts is presented in Figs. 9-10. Differences between the average temperature rises on the unexposed surface of test specimens with insulation inserts and glass panes type No. 1 and type No. 2 is presented in Figs. 11-12.

\section{DISCUSSION}

In the Figs. 3, 4 it can be observed that average temperature rises on unexposed surface of glass panes are similar despite of the different heating conditions temperatures in the furnace (external or internal fire exposure, Fig. 3.

In the Figs. 5-8 it can be observed that average temperature rises on unexposed surface of profiles are greater for internal fire exposure.

In the Figs. 9-12 it can be observed that the average temperature rises are greater on the unexposed surface of profiles with insulation inserts of type No. 1.

Moreover it can be observed that average temperature rises on transoms and mullions are similar for each test (specified curve and insulation inserts type).

Despite of the difference in cross - section of mullion and transom profiles temperature rises measured on them are similar. This phenomena is probably observed because additional insulation inserts were applied between the profile and the glass pane, providing that dimensions between the insulation inserts and glass pane surface is equal for transom and mullion profiles (see $\mathrm{X}$ dimension in Fig. 1). 


\section{MATEC Web of Conferences}

\section{References}

[1] EN 1363-1:2012 Fire resistance tests - Part 1 General requirements

[2] EN 1363-2:1999 Fire resistance tests - Part 2 Alternative and additional procedures

[3] EN 1364-3:2006 Fire resistance tests for non-loadbearing elements - Part. 3: Curtain walling Full configuration (complete assembly)

[4] EN 13501-2+A1:2009 Fire classification of construction products and buildings elements - Part 2: Classification using data from fire resistance tests, excluding ventilation services)

[5] B. Sȩdłak, "Badania odporności ogniowej przeszklonych ścian osłonowych - Czȩść 1", Świat Szkła, R.17, nr 9, 52-54, 2012 (in Polish)

[6] B. Sȩdłak, "Badania odporności ogniowej przeszklonych ścian osłonowych - Czȩść 2", Świat Szkła, R.17, nr 10, 53-58, 2012 (in Polish) 